\title{
Molecular Detection Of Hematodinium Sp Infecting The Blue Crab, Callinectes Sapidus
}

\author{
Hamish J. Small \\ Virginia Institute of Marine Science \\ Jeffrey D. Shields \\ Virginia Institute of Marine Science \\ Karen Hudson \\ Virginia Institute of Marine Science \\ Kimberly S. Reece \\ Virginia Institute of Marine Science
}

Follow this and additional works at: https://scholarworks.wm.edu/vimsarticles

Part of the Marine Biology Commons

\section{Recommended Citation}

Small, Hamish J.; Shields, Jeffrey D.; Hudson, Karen; and Reece, Kimberly S., "Molecular Detection Of Hematodinium Sp Infecting The Blue Crab, Callinectes Sapidus" (2007). VIMS Articles. 446.

https://scholarworks.wm.edu/vimsarticles/446

This Article is brought to you for free and open access by the Virginia Institute of Marine Science at W\&M ScholarWorks. It has been accepted for inclusion in VIMS Articles by an authorized administrator of W\&M ScholarWorks. For more information, please contact scholarworks@wm.edu. 


\title{
MOLECULAR DETECTION OF HEMATODINIUM SP. INFECTING THE BLUE CRAB, CALLINECTES SAPIDUS
}

\author{
HAMISH J. SMALL, ${ }^{1,2 *}$ JEFFREY D. SHIELDS, ${ }^{1}$ KAREN L. HUDSON ${ }^{1}$ AND \\ KIMBERLY S. REECE ${ }^{1}$ \\ ${ }^{1}$ Virginia Institute of Marine Science, College of William and Mary, Gloucester Point, Virginia 23062; \\ ${ }^{2}$ Centre for Environment, Fisheries \& Aquaculture Science (CEFAS), Weymouth Laboratory, Barrack \\ Road, The Nothe, Weymouth, Dorset DT4 8UB, United Kingdom(present address)
}

\begin{abstract}
Species of Hematodinium are endoparasitic dinoflagellates of crustaceans. Certain stages of the parasites can be very difficult to detect in the hemolymph of their hosts, because the trophic stages resemble hemocytes, and they can occur at relatively low densities, making diagnosis by microscopy difficult. We developed a polymerase chain reaction (PCR) assay to detect the Hematodinium sp. infecting the blue crab, Callinectes sapidus, based on the amplification of the parasite's first internal transcribed spacer region (ITS1) of the ribosomal RNA (rRNA) gene complex. The PCR assay was combined with a restriction endonucleases digestion ( $B s g \mathrm{I}$ ) of the amplification products to differentiate between different forms of Hematodinium from different hosts. The assay had a limit of detection equivalent to 0.3 parasites per $100-\mu \mathrm{L}$ hemolymph. In addition, two oligonucleotide DNA probes were designed to target the 18S rRNA gene sequence of the parasite, facilitating detection in situ in crustacean tissues. These probes appear to target several, if not all species within the genus, because they labeled all isolates of Hematodinium tested in this study, whereas they were not hybridizing to other parasite species. The PCR-RFLP assay will be invaluable for future studies investigating parasite prevalence, the existence of secondary hosts or environmental reservoirs, and modes of transmission, whereas the DNA probes will be useful for confirming and localizing Hematodinium parasites in crustacean tissues.
\end{abstract}

KEY WORDS: Hematodinium, Callinectes sapidus, PCR-RFLP, DNA Probe

\section{INTRODUCTION}

Blue crabs, Callinectes sapidus, from the eastern seaboard of the United States are seasonally infected by a species of parasitic dinoflagellate in the genus Hematodinium. The parasite is pathogenic, and in most cases, kills its crab host by energy depletion or tissue disruption (Shields \& Squyars 2000, Shields et al. 2003). The disease is prevalent in C. sapidus from Delaware to Florida and those in the Gulf of Mexico, but it is limited to salinities greater than $12 \mathrm{ppt}$ (Newman \& Johnson 1975, Messick \& Shields 2000). Epizootics show a distinct seasonality, with outbreaks most frequent in fall months (Messick 1994, Messick \& Shields 2000). During outbreaks, disease prevalences can reach $100 \%$ in juvenile crabs and up to $70 \%$ in mature crabs (Messick 1994).

At present, there are only two described species of Hematodinium. The type species $H$. perezi was originally described from the shore crab, Carcinus maenas, and the harbor crab, Liocarcinus depurator, from France (Chatton \& Poisson 1931). A second species, H. australis, was described from the sand crab, Portunus pelagicus, from Australia (Hudson \& Shields 1994). Hematodinium perezi was subsequently identified as the species infecting C. sapidus (Newman \& Johnson 1975, MacLean \& Ruddell 1978); however, recent DNA sequence data suggests otherwise (Small et al. 2006b). There are numerous reports of Hematodinium-like species infecting other crustaceans (see Stentiford \& Shields 2005, for review), many of which support commercially important fisheries.

Diagnosis of Hematodinium infection in C. sapidus has previously relied on microscopic observation of fixed and stained (hematoxylin and eosin/giemsa) hemolymph samples

*Corresponding author. E-mail: hamish.small@cefas.co.uk and tissue sections for the presence of parasites (Messick 1994, Messick \& Shields 2000) or the use of neutral red dye to stain parasite lysosomes in fresh hemolymph preparations (Chatton \& Poisson 1931, Small 2004, Stentiford \& Shields 2005). Increasingly, molecular diagnostics are being developed and used in assessments of many different fish and shellfish diseases (for review see Cunningham 2002), and this is also the case for Hematodinium species. Hudson and Adlard (1994) developed a generic primer set for the Hematodinium spp. infecting C. sapidus, the Norway lobster, Nephrops norvegicus, the snow crab, Chionoecetes opilio, and the tanner crab, C. bairdi. However, in our hands this primer set produces multiple amplification products using Hematodinium DNA preparations from various crustaceans, making its use as a diagnostic assay unreliable (H. Small, personal observation). Recently, Gruebl et al. (2002) and Frischer et al. (2006) developed a polymerase chain reaction (PCR) and Real Time PCR assay, respectively, to detect Hematodinium infections in C. sapidus; however, both primer sets used in these assays anneal to regions within the highly conserved 18S rRNA gene, and as such, these assays are most likely only genus-specific. Given the ability of many marine pathogens and strains to vary in their virulence and pathogenicity (e.g., Bushek \& Allen 1996, Wang et al. 1999, Stewart et al. 2004) there is an obvious need for a species-specific diagnostic assay for this economically significant pathogen.

In this study, the first internal transcribed spacer region (ITS1) of the ribosomal rRNA gene complex was amplified and sequenced from the Hematodinium sp. infecting $C$. sapidus from Virginia, USA. Our objective was to analyze the ITS1 region sequence as a target for the development of a species-specific PCR-based diagnostic assay. In addition, the 18S rRNA gene from the parasite was also sequenced, and informative regions of that sequence were used for the design and development of in situ DNA probes for Hematodinium spp. 


\section{MATERIALS AND METHODS}

\section{Collection of Experimental Animals}

Naïve, uninfected C. sapidus were obtained from the VIMS trawl and dredge surveys in low salinity waters outside enzootic locations. Infected crabs were obtained from high-salinity waters on the Delmarva Peninsula, and from the lower reaches of Chesapeake Bay (VIMS surveys, a commercial waterman, and our own trawl effort). Crabs were placed in plastic bags on newspaper-covered ice and transported to the laboratory.

Infected $C$. sapidus were identified using smears of fresh hemolymph mixed with neutral red, as described by Stentiford and Shields (2005). Briefly, approximately $1 \mathrm{~mL}$ of crab hemolymph was removed from the fifth walking leg using a sterile syringe and a 27 ga. needle. Ethanol (70\%) was used to sterilize the surface of the crab prior to removal of hemolymph. An equal volume of neutral red $(0.04 \%(\mathrm{w} / \mathrm{v})$ in $1 \times$ phosphate buffered saline (PBS) was mixed with a subsample of hemolymph, and the sample placed on a glass slide and viewed under light microscopy to assess the presence of parasites. Selected samples were also placed on a hemocytometer to estimate parasite density prior to DNA extraction (see below). Dissections were performed on a subset of infected animals. For histological preparations, various tissues (hepatopancreas, heart, gill) were dissected and fixed in Davidson's seawater fixative (Shaw \& Battle 1957, $20 \mathrm{~mL}$ formalin [40\% v/v], $10 \mathrm{~mL}$ glycerol, $10 \mathrm{~mL}$ glacial acetic acid, $30 \mathrm{~mL} \mathrm{100 \%} \mathrm{ethanol,} 30 \mathrm{~mL}$ seawater), then processed through routine paraffin procedures. Davidson's fixed-tissue sections, and ethanol preserved hemolymph and tissue samples from other crustaceans infected with Hematodinium spp. were also obtained from colleagues.

\section{DNA Extraction}

Total DNA was isolated from crab tissue $(50-100 \mathrm{mg})$ and whole hemolymph $(100 \mu \mathrm{L})$ samples (both ethanol preserved and fresh) using a DNeasy Tissue Kit (Qiagen Inc., Valencia, CA) according to the manufacturer's instructions. The DNA was quantified using a Hoefer DyNA Quant 200 fluorometer (Pharmacia Biotech Inc., Piscataway, NJ) and stored at $-20^{\circ} \mathrm{C}$.

\section{Polymerase Chain Reaction Amplifications}

The $18 \mathrm{~S}$ region from the Hematodinium sp. infecting the C. sapidus was amplified from a single genomic DNA sample using "universal" eukaryotic primers (Medlin et al. 1988) and conditions previously described (Flores et al. 1996, Moss et al. 2006). To identify unique DNA sequences specific to the parasite infecting C. sapidus, and to assess intraspecific variation, the ITS1 region was amplified from two genomic DNA samples (isolated from two different infected crabs) using the forward primer 5' GTTCCCCTTGAACGAGGAATTC 3' and reverse primer $5^{\prime}$ CGCATTTCGCTGCGTTCTTC 3', which have been described previously (Hudson \& Adlard 1994). Amplification reactions were carried out in a DNA Engine thermocycler (MJ Research Inc., Waltham, MA) and contained $60 \mathrm{mM}$ Tris-SO $\mathrm{SO}_{4}(\mathrm{pH} 8.9), 18 \mathrm{mM}\left(\mathrm{NH}_{4}\right)_{2} \mathrm{SO}_{4}, 2 \mathrm{mM}$ $\mathrm{MgSO}_{4}, 25 \mathrm{ng}$ genomic DNA, $0.2 \mathrm{mM}$ each dNTP, $2.5 \mathrm{mM}$ each primer, 1 unit Platinum high fidelity Taq polymerase (Invitrogen, Carlsbad, CA), and sterile deionized water to a final volume of $20 \mu \mathrm{L}$. Thermocycling conditions were as follows: denaturation at $94^{\circ} \mathrm{C}$ for $1 \mathrm{~min}$; primer annealing at $52^{\circ} \mathrm{C}$ for $30 \mathrm{sec}$; chain extension at $72^{\circ} \mathrm{C}$ for $90 \mathrm{sec}$; repeated for 35 cycles, with a final 5 -min extension at $72^{\circ} \mathrm{C}$.

\section{Cloning and Sequencing}

Amplification products from the $18 \mathrm{~S}$ rRNA PCR were cloned into the pCR 2.1 vector using a TA Cloning Kit (Invitrogen) following the recommended protocol. To generate the consensus $18 \mathrm{~S}$ sequence, four clones were sequenced by cycle sequencing using the Thermo Sequenase kit (Amersham Biosciences, Piscataway, NJ), and IRD41-labeled M13 forward and reverse primers (LI-COR, Lincoln, NE). Reactions were run on a LI-COR automated sequencer (Model 4200).

Amplification products from the ITS1 region PCR reactions were visualized by agarose gel electrophoresis $(2 \% \mathrm{w} / \mathrm{v})$, stained with ethidium bromide and viewed under a UV light source. Amplification products of approximately 680-bp were excised from the gel using a sterile scalpel and purified using a QIAquick gel extraction kit (Qiagen). Two independent ITS1 region PCR reactions were performed for both genomic DNA samples. The purified 680-bp amplification products for each sample were then combined prior to adenine (A)-tailing, to ensure efficient ligation into the plasmid vector. The A-tail reactions contained $10 \mu \mathrm{L}$ of the purified amplification product, $10 \mathrm{mM}$ Tris- $\mathrm{HCl}, \mathrm{pH} 8.3,50 \mathrm{mM} \mathrm{KCl}, 1.5 \mathrm{mM} \mathrm{MgCl} 2,0.001 \%$ (w/v) gelatine, $30 \mu \mathrm{M}$ dATP, $1 \mathrm{U}$ Taq polymerase (Applied Biosystems, Foster City, CA), and sterile deionized water to a final volume of $15 \mu \mathrm{L}$. Samples were then incubated at $72^{\circ} \mathrm{C}$ for 10 min. A-tail reaction products were ligated into the pCR4TOPO vector (Invitrogen) and used to transform Escherichia coli (Top 10 chemically competent) by heat shock according to the manufacturer's instructions. Recombinant plasmids were purified using a miniprep kit (Qiagen) according to the manufacturer's instructions. To assess sequence variation in the ITS1 region, plasmid inserts in five clones from each sample were bidirectionally sequenced in triplicate using the Big Dye Terminator v3.1 Cycle Sequencing Kit (Applied Biosystems) with M13 sequencing primers using $1 / 8$ of the recommended reaction size dictated in the manufacturer's protocols. Thermocycling parameters were as follows: 25 cycles of $96^{\circ} \mathrm{C}$ for $1 \mathrm{~min}, 96^{\circ} \mathrm{C}$ for $10 \mathrm{sec}, 50^{\circ} \mathrm{C}$ for $5 \mathrm{sec}, 60^{\circ} \mathrm{C}$ for $4 \mathrm{~min}$, followed by a final incubation at $4^{\circ} \mathrm{C}$. The sequencing reaction products were precipitated using ethanol/sodium acetate (ABI User Bulletin, April 11, 2002). Precipitated sequencing reactions were resuspended in $20 \mu \mathrm{L}$ of Hi-Di formamide (Applied Biosystems) and $10 \mu \mathrm{L}$ of each was electrophoresed on an 3130 Prism genetic analyzer (Applied Biosystems).

\section{Development and Application of PCR-RFLP Assay}

Hematodinium ITS1 region sequences obtained from infected $C$. sapidus were aligned and compared with published Hematodinium spp. sequences (Hudson \& Adlard 1996, Gruebl et al. 2002, Small et al. 2006a) and other ITS1 region Hematodinium spp. sequences from $L$. depurator, $N$. norvegicus, the Chinese swimming crab, Portunus trituberculatus, the edible crab, Cancer pagurus, and the hermit crab, Pagurus bernhardus, (H. Small, unpublished data) using the Clustal-W algorithm in the MacVector versus 8.0.2 DNA sequence analysis package (Accelrys Inc., San Diego, CA). The Hematodinium spp. sequences from C. sapidus, L. depurator, and P. trituberculatus 
were so similar that designing primers to specifically amplify DNA from a single parasite species from the one host was not feasible. Therefore, aligned sequences were subjected to virtual digestion using the restriction enzyme analysis option in the MacVector sequence analysis package to identify restriction enzymes that could be used to distinguish the Hematodinium sp. infecting $C$. sapidus from the others. Potentially useful restriction endonucleases identified by the virtual digestion analyses were then tested by PCR amplification of the ITS1 region and subsequent restriction digestion of amplification products in multiple samples from each host species. The digested products were separated by $2 \%$ agarose $(\mathrm{w} / \mathrm{v})$ gel electrophoresis and visualized as described earlier.

PCR primers (HITS1F 5' -CATTCACCGTGAACCTTAGCC-3' and HITS1R 5' -CTAGTCATACGTTTGAAGAAAGCC- $\left.3^{\prime}\right)$ were designed to specifically amplify the ITS1 region from the Hematodinium spp. infecting C. sapidus, L. depurator, and $P$. trituberculatus, producing a 302-bp reaction product (see Table 1). Both primers anneal to the $5^{\prime}$ and $3^{\prime}$ end of the variable ITS1 region. The amplification reaction mixtures contained $10 \mathrm{mM}$ Tris- $\mathrm{HCl}, \mathrm{pH} 8.3,50 \mathrm{mM} \mathrm{KCl}, 1.5 \mathrm{mM}$ $\mathrm{MgCl}_{2}$, approximately $50 \mathrm{ng}$ of genomic DNA, $0.1 \mathrm{mM}$ of each dNTP, $5 \mathrm{mM}$ of each primer, 1 unit of Taq polymerase, and sterile demonized water to a final volume of $20 \mu \mathrm{L}$. Thermocycling conditions were as follows: denaturation at $94^{\circ} \mathrm{C}$ for $30 \mathrm{sec}$; primer annealing at $56^{\circ} \mathrm{C}$ for $30 \mathrm{sec}$; chain extension at $72^{\circ} \mathrm{C}$ for $90 \mathrm{sec}$; repeated for 35 cycles, with a final 5-min extension. Amplification products $(5-\mu \mathrm{L}$ aliquot) were visualized by agarose gel electrophoresis $(2 \% \mathrm{w} / \mathrm{v})$, stained with ethidium bromide and viewed under a UV light source. Amplified Hematodinium ITS1 region products were digested independently with each of the diagnostic restriction enzymes ( $B s g$ I, $S f c$ I and $B l p \mathrm{I}$ ) identified in the virtual restriction enzyme digestion analysis following manufacturer protocols (New England Biolabs Inc., Ipswich, MA). The digested products were separated by $2 \%$ agarose $(\mathrm{w} / \mathrm{v})$ gel electrophoresis and visualized as described earlier.

The specificity of the PCR primers was tested against DNA samples (see Table 2) from infected and uninfected C. sapidus, several other protozoan parasites, including Perkinsus marinus, Haplosporidium nelsoni, H. costale, Bonamia spp., and Quahog Parasite Unknown (QPX), other dinoflagellate species (Karlodinium micrum, Pfiesteria piscicida, and P. shumwayae), a parasitic ciliate from C. sapidus (Mesanophrys chesapeakensis) and other samples of Hematodinium spp. (from N. norvegicus, $C$. pagurus, and $P$. bernhardus). PCR reactions were carried out as described earlier. In addition, possible intraspecific variation in the ITS1 region (primer binding domains and restriction endonucleases recognition motif) between Hematodinium sp.

TABLE 1.

Primer and probe sequences for detection of the Hematodinium sp. infecting $C$. sapidus.

\begin{tabular}{cl}
\hline \hline Primer/Probe Name & \multicolumn{1}{c}{ Primer/Probe Sequence $\left(\mathbf{5}^{\prime} \mathbf{- 3}^{\prime}\right)$} \\
\hline HITS1F & CATTCACCGTGAACCTTAGCC \\
HITS1R & CTAGTCATACGTTTGAAGAAAGCC \\
H-680 & ACCAGATGATCACCCAAAG \\
H-1425 & GTTTCCCACGTATCCGAAG \\
\hline
\end{tabular}

TABLE 2.

Screening results for the specificity of the HITS1F and HITS1R primer set against various metazoans and protozoans.

\begin{tabular}{lc}
\hline \hline \multicolumn{1}{c}{ DNA Template } & PCR Result \\
\hline Infected host material & \\
Callinectes sapidus w/Hematodinium sp. $(n=18)$ & + \\
Liocarcinus depurator w/Hematodinium sp. $(n=4)$ & + \\
Portunus trituberculatus w/Hematodinium sp. $(n=4)$ & + \\
Chionoecetes opilio w/Hematodinium sp. $(n=4)$ & - \\
Nephrops norvegicus w/Hematodinium sp. $(n=6)$ & - \\
Cancer pagurus w/Hematodinium sp. $(n=6)$ & - \\
Callinectes sapidus w/Mesanophrys chesapeakensis & - \\
Crassostrea virginica w/Haplosporidium costale & - \\
Crassostrea virginica w/Haplosporidium nelsoni & - \\
Crassostrea virginica w/Perkinsus marinus & - \\
Crassostrea ariakensis w/Bonamia sp. & - \\
Culture material & - \\
Hematodinium sp. from Nephrops norvegicus & - \\
Hematodinium sp. from Pagurus bernhardus & - \\
Karlodinium micrum & - \\
Cochlodinium sp. & - \\
Pfiesteria shumwayae (CCMP 2089) & - \\
Pfiesteria piscicida (CCMP 1830) & - \\
Prorocentrum micans & - \\
Perkinsus marinus (ATCC 50439) & - \\
\hline
\end{tabular}

infecting $C$. sapidus from geographically separate locations (Virginia and Georgia) was assessed by PCR-RFLP for 10 and 8 specimens of genomic DNA from individual infected crabs from each state, respectively.

The sensitivity of the PCR primers was tested by serial dilution of a genomic DNA sample extracted from C. sapidus infected hemolymph. The number of parasite cells in the infected hemolymph sample was estimated using neutral red (as previously) and an improved Neubauer hemocytometer. PCR reactions were carried out as described earlier. Five microliters of the PCR reactions were subject to $2 \%$ agarose $(\mathrm{w} / \mathrm{v})$ gel electrophoresis and visualized as described earlier.

\section{Development and Application of DNA Probes}

The 18S rRNA sequence from the Hematodinium sp. infecting C. sapidus was aligned with the only other published Hematodinium 18S sequence (Gruebl et al. 2002), as well as $18 \mathrm{~S}$ rRNA sequences from the syndinid Syndinium turbo (DQ146405), P. shumwayae (AY245694), P. piscicida (AY245693), P. marinus (AF497479), H. nelsoni (X74131), and the parasitic dinoflagellate Amoebophrya sp. (AF069516). From this alignment, we designed two 19-bp DNA probes (H-680 and $\mathrm{H}-1425)$ that were specific to the Hematodinium 18S rRNA sequence (see Results). Custom probes were synthesized with the incorporation of digoxigenin at the $5^{\prime}$ end (Operon Biotechnologies Inc., Huntsville AL).

Paraffin-embedded tissue sections were cut at $6-\mu \mathrm{m}$ thickness, placed on positively charged slides (Fisher Scientific, Pittsburgh, PA), and baked in an oven at $40^{\circ} \mathrm{C}$ overnight to dry. Sections were dewaxed, rehydrated in an ethanol series, and washed in distilled water. The sections were permeabilized with $50 \mu \mathrm{g} \mathrm{mL}^{-1}$ pronase in $\mathrm{P}$ buffer $(50 \mathrm{mM}$ Tris $\mathrm{HCl}, 0.5 \mathrm{mM}$ EDTA, pH 7.5) at $37^{\circ} \mathrm{C}$ for $15 \mathrm{~min}$. Proteolysis was halted by 
two 5-min washes in $\mathrm{P}$ buffer followed by equilibration in $2 \times$ $\mathrm{SSC}(20 \times \mathrm{SSC}=3 \mathrm{M} \mathrm{NaCl}, 0.3 \mathrm{M}$ Na-citrate, $\mathrm{pH}$ 7.4) for $10 \mathrm{~min}$. The slides were placed in a slide cassette and incubated in $15 \mathrm{~mL}$ of prehybridization buffer $(4 \times \mathrm{SSC}, 50 \%$ Formamide, $5 \times$ Dendhart solution, $0.5 \mathrm{mg} \mathrm{mL}^{-1}$ heat-denatured salmon sperm DNA) for $1 \mathrm{~h}$ at $37^{\circ} \mathrm{C}$. The prehybridization buffer was decanted and replaced with $60-\mu \mathrm{L}$ prehybridization buffer containing $8 \mathrm{ng} \mu \mathrm{L}^{-1}$ of the DIG-labeled oligonucleotide probe (either H-680 or H-1425). The sections were covered with plastic coverslips, placed on a heating block at $90^{\circ} \mathrm{C}$ for 2 min to denature the target DNA, and placed immediately on ice for $1 \mathrm{~min}$ before placing them in a humid chamber at $42^{\circ} \mathrm{C}$ for overnight hybridization. Posthybridization washes included $2 \times \mathrm{SSC}$ twice at room temperature $\left(25^{\circ} \mathrm{C}\right)$ for $5 \mathrm{~min}, 1 \times \mathrm{SSC}$ twice at room temperature for $5 \mathrm{~min}, 0.5 \times \mathrm{SSC}$ twice at $42^{\circ} \mathrm{C}$ for $10 \mathrm{~min}$, followed by equilibration into maleic acid buffer (100 mM maleic acid, $150 \mathrm{mM} \mathrm{NaCl}, \mathrm{pH} 7.5$ ). The sections were blocked with maleic acid buffer plus $2 \%$ (v/v) normal sheep serum for $30 \mathrm{~min}$ at room temperature. Antidigoxigeninalkaline phosphatase conjugate (Roche, Indianapolis, IN) was diluted 1:500 in maleic acid buffer plus $1 \%(\mathrm{v} / \mathrm{v})$ normal sheep serum and sections were incubated with $100 \mu \mathrm{L}$ of the diluted antibody for $3 \mathrm{~h}$ in a humid chamber at room temperature. Unbound antibody was removed by two 5-min washes in $\mathrm{Ab}$ wash buffer (maleic acid buffer $+0.3 \%$ [v/v] Tween 20), followed by two 5 -min washes in detection buffer $(100 \mathrm{mM}$ Tris- $\mathrm{HCl}, 100 \mathrm{mM} \mathrm{NaCl}, 50 \mathrm{Mm} \mathrm{MgCl}, \mathrm{pH}$ 9.5). The slides were placed in a slide cassette and incubated in the dark for $2 \mathrm{~h}$ at room temperature with $16 \mathrm{~mL}$ of color development solution [15.872 $\mathrm{mL}$ detection buffer $+72 \mu \mathrm{L}$ nitro blue tetrazolium $(\mathrm{NBT})+56 \mu \mathrm{L}$ 5-bromo-4-chloro-3-indolyl phosphate (BCIP)]. The color reaction was stopped with a TE buffer (10 mM Tris-HCl, $1 \mathrm{mM}$ EDTA, pH 8.0) wash followed by equilibration into double distilled $\mathrm{H}_{2} \mathrm{O}$. Sections were counterstained in $1 \%$ Eosin $\mathrm{Y}$ solution $(\mathrm{w} / \mathrm{v})$ for $1 \mathrm{~min}$, followed by ethanol dehydration and mounted in histological mounting medium (Permount). Sections were examined and images documented using an Olympus BX51 microscope equipped with a Nikon DXM 1200 digital camera (Act 1 software, Nikon). To test probe specificity, sections of uninfected C. sapidus tissue, samples of Hematodinium spp. from different crustaceans, and other parasitic protozoa were processed as described earlier (Table 3). Negative controls included sections assayed without the addition of the DNA probe.

\section{RESULTS}

\section{S rRNA Gene and ITS1 Region Sequences}

The four 18S rRNA gene sequences from the Hematodinium sp. infecting $C$. sapidus were identical and were combined to produce a consensus sequence (Gen Bank Accession No. DQ925237). Alignment of this sequence with other 18S rRNA gene sequences from various parasites and dinoflagellates (P. marinus, P. shumwayae, P. piscicida, S. turbo, H. nelsoni, and Amoebophrya sp.) resulted in the identification of regions unique to the Hematodinium sp. from C. sapidus, where two 19bp DNA probes for in situ hybridization were designed and used in assays described earlier (see Table 1 and Fig. 1). The $18 \mathrm{~S}$ rRNA sequence of the Hematodinium sp. from C. sapidus from Virginia was $100 \%$ identical over 1682-bp to the Hematodinium
TABLE 3.

Screening results for the specificity of the H-680 and H-1425 DNA probes against various metazoans and protozoans.

\begin{tabular}{|c|c|}
\hline Test Material & $\begin{array}{l}\mathrm{H}-680 \text { and } \mathrm{H}-1425 \\
\text { Probe Results }\end{array}$ \\
\hline Callinectes sapidus w/Hematodinium $\mathrm{sp}$. & + \\
\hline Liocarcinus depurator $\mathrm{w} /$ Hematodinium $\mathrm{sp}$. & + \\
\hline Chionoecetes opilio $\mathrm{w} /$ Hematodinium $\mathrm{sp}$. & + \\
\hline Chionoecetes bairdi $\mathrm{w} /$ Hematodinium $\mathrm{sp}$. & + \\
\hline Nephrops norvegicus w/Hematodinium sp. & + \\
\hline Cancer pagurus $\mathrm{w} /$ Hematodinium $\mathrm{sp}$. & + \\
\hline Callinectes sapidus & - \\
\hline Callinectes sapidus $\mathrm{w} /$ Mesanophrys chesapeakensis & - \\
\hline Crassostrea virginica $\mathrm{w} /$ Haplosporidium costale & - \\
\hline Crassostrea virginica $\mathrm{w} /$ Haplosporidium nelsoni & - \\
\hline Crassostrea virginica $\mathrm{w} /$ Perkinsus marinus & - \\
\hline Pandalus platyceros $w /$ spot prawn parasite & - \\
\hline
\end{tabular}

sp. infecting C. sapidus from Georgia, USA (GenBank Accession No. AF286023, Gruebl et al. 2002).

ITS 1 region sequences of 10 clones ( 2 samples, 5 clones each) from the Hematodinium sp. infecting C. sapidus were highly conserved (99\% similarity) (Gen Bank Accession Nos. DQ925227-DQ925236). Nine of the 10 clones were identical in length (351-bp), whereas the 10th clone sequence was 354-bp in length because of a TAA insertion. We found five slightly different sequences among our ITS1 region clones (Fig. 2) with six clones having the same sequence, one having an TAA insertion extending a microsatellite repeat region, and the other three having single polymorphic nucleotides at positions 185 $(\mathrm{G}>\mathrm{T}), 263(\mathrm{~T}>\mathrm{C}), 283(\mathrm{~T}>\mathrm{C})$, and $319(\mathrm{C}>\mathrm{T})$. Alignment of partial ITS1 sequences from other species of Hematodinium (Hudson \& Adlard 1996, Small et al. 2006a) indicated that the ITS1 region sequences from the Hematodinium sp. in the blue crab generated in this study were only $82 \%$ similar to the previously published ITS1 sequence for presumably the same Hematodinium sp. from C. sapidus, and only $46 \%$ similar to ITS1 region sequences reported for the Hematodinium sp. from N. norvegicus.

\section{PCR-RFLP Assay}

The ten clone sequences from the ITS1 region were sufficiently conserved at the $5^{\prime}$ and $3^{\prime}$ ends so that PCR primers could be designed to target these domains. The forward primer (HITS1F) was designed to anneal at bp 42/63-bp downstream of the $18 \mathrm{~S} / \mathrm{ITS} 1$ boundary, whereas the reverse primer (HITS1R) was designed to anneal at bp 4/27-bp upstream of the ITS1/5.8S boundary (Fig. 1 ). The PCR primers HITS1F and HITS1R successfully amplified a 302-bp fragment (based on sequence analysis) of the ITS1 region from Hematodinium sp.

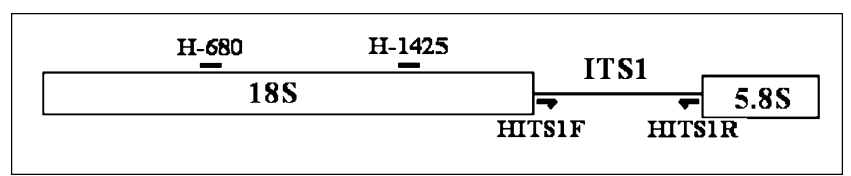

Figure 1. Diagrammatic representation of the primer and probe anchor locations in the Hematodinium 18S ribosomal RNA gene and ITS1 spacer region. 


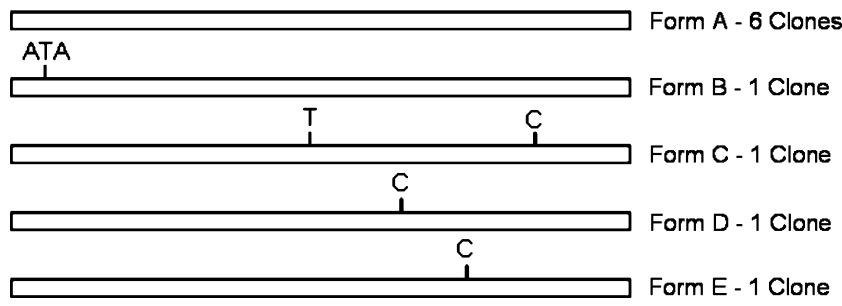

Figure 2. Nucleotide variation in the ITS1 region of the Hematodinium sp. infecting Callinectes sapidus. Five different ITS1 forms were detected when 10 clones were sequenced from 2 genomic DNA samples $(5$ clones per sample). A dominant form (A) was represented in 6 of the 10 clones, and the remaining 4 forms unique to single genomes ( $B$ to $E$ ).

infecting C. sapidus (Fig. 3A). In addition, the primers also amplified a comparable length ITS1 region fragment from the Hematodinium spp. infecting $L$. depurator and $P$. trituberculatus (Fig. 3A). The primers did not produce amplification products for any of the other Hematodinium spp., dinoflagellate, parasite, or host DNA templates used (Table 2). Restriction enzyme digestion of the positive amplification products by Bsg I resulted in a 2-band digestion profile that was unique to the Hematodinium sp. from C. sapidus (Fig. 3B). The diagnostic 2-band PCR-RFLP digestion profile was observed for infected C. sapidus from Virginia and Coastal Savannah, GA, USA (data not shown). The limit of sensitivity of the PCR assay was found to be 0.3 parasites per $100 \mu \mathrm{L}$ of hemolymph (Fig. 4).

\section{DNA Probe Specificity}

Both DNA Probes (H-680 and H-1425) hybridized to all of the Hematodinium cells present in paraffin-embedded tissue sections prepared from the various infected crustacean species (Table 3, Fig. 5A to E). There was no background hybridization to any host tissues for the crustacean samples analyzed or to other protozoan pathogens such as $P$. marinus (Fig. 5F), H. nelsoni, or a spot prawn parasite of Pandalus platyceros, previously though to be a Hematodinium sp. (Bower et al. 1993). Hematodinium cells were localized in the myocardium of the heart and the hemal spaces in the hepatopancreas of C. sapidus,
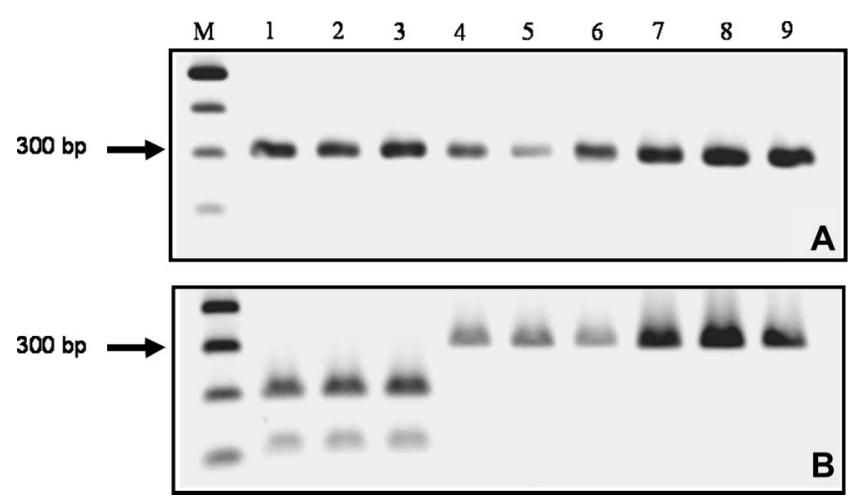

Figure 3. PCR-RFLP assay for detection of the Hematodinium sp. infecting Callinectes sapidus. (A) PCR amplification of the ITS1 region from Hematodinium spp. infecting $C$. sapidus (lanes 1-3), Liocarcinus depurator (lanes 4-6), and Portunus trituberculatus (lanes 7-9). (B) Restriction enzyme digestion of amplified products using Bsg I. M = 100 bp molecular weight marker. and in the hemal spaces in the hepatopancreas of $N$. norvegicus and C. opilio (Fig. 5B to E).

\section{DISCUSSION}

We have amplified and sequenced both the 18S rRNA gene and the ITS1 region from the Hematodinium sp. infecting C. sapidus with the aim of developing a species-specific PCRbased diagnostic assay. Primers developed to amplify the ITS1 region for the PCR assay also amplified the ITS1 region from Hematodinium spp. infecting L. depurator and P. trituberculatus; however, restriction enzyme digestion profiles of the amplification products were used to successfully differentiate the Hematodinium sp. infecting C. sapidus. In addition, two oligonucleotide DNA probes were developed to detect Hematodinium spp. infections in crustaceans. The probes bound to all Hematodinium species tested and will be a useful resource to confirm and localize Hematodinium infection in field and laboratory samples.

Methods used for diagnosis of Hematodinium spp. infection in crustaceans have previously involved the use of traditional light microscopy/histology (Meyers et al. 1987, Field et al. 1992, Messick 1994, Wilhelm \& Mialhe 1996), the assessment of the carapace for discoloration (Meyers et al. 1987, Field et al. 1992, Taylor \& Khan 1995, Briggs \& McAliskey 2002, Stentiford et al. 2002), the aggregation of parasites in the pleopod and swimming legs of crabs (Field et al. 1992, Messick 1994, Field \& Appleton 1995, Tärnlund 2000), antibody-based assays (Field \& Appleton 1996, Stentiford et al. 2001, Small et al. 2002), and DNA-based techniques (Hudson \& Adlard 1994, Gruebl et al. 2002, Frischer et al. 2006, Small et al. 2006a). In particular, Hematodinium sp. infections in C. sapidus have been identified by microscopic analysis of fixed and stained hemolymph samples and tissue sections (Newman \& Johnson 1975, Messick \& Shields 2000, Sheppard et al. 2003), the use of neutral red dye (Small 2004, Stentiford \& Shields 2005), and two PCR-based assays (Gruebl et al. 2002, Frischer et al. 2006). In the latter molecular assays, a set of primers binding in the $18 \mathrm{~S}$ rRNA gene was used as the basis for a standard PCR and real time diagnostic assays. Ribosomal 18S rRNA genes however, are known to diverge slowly during speciation, and as such are well conserved between species (Bargues et al. 2000). That is not to say that species-specific assays cannot be developed using these regions, as has successfully been achieved for $P$. piscicida (Rublee et al. 1999), Martelia refringens (Le Roux et al. 1999), and Kudoa neurophila (Grossel et al. 2005), rather, that the PCR primers developed by Gruebl et al. (2002) and used by Frischer

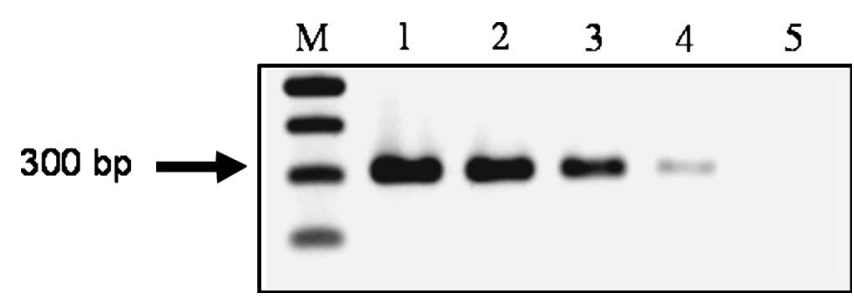

Figure 4. Sensitivity of PCR assay for detection of the Hematodinium sp. infecting Callinectes sapidus. Serial dilution of genomic DNA extracted from a sample of infected hemolymph from C. sapidus. Lanes 1-5: infected hemolymph DNA template equivalent to $300,30,3,0.3$ parasite. $M=100$ bp molecular weight marker. 

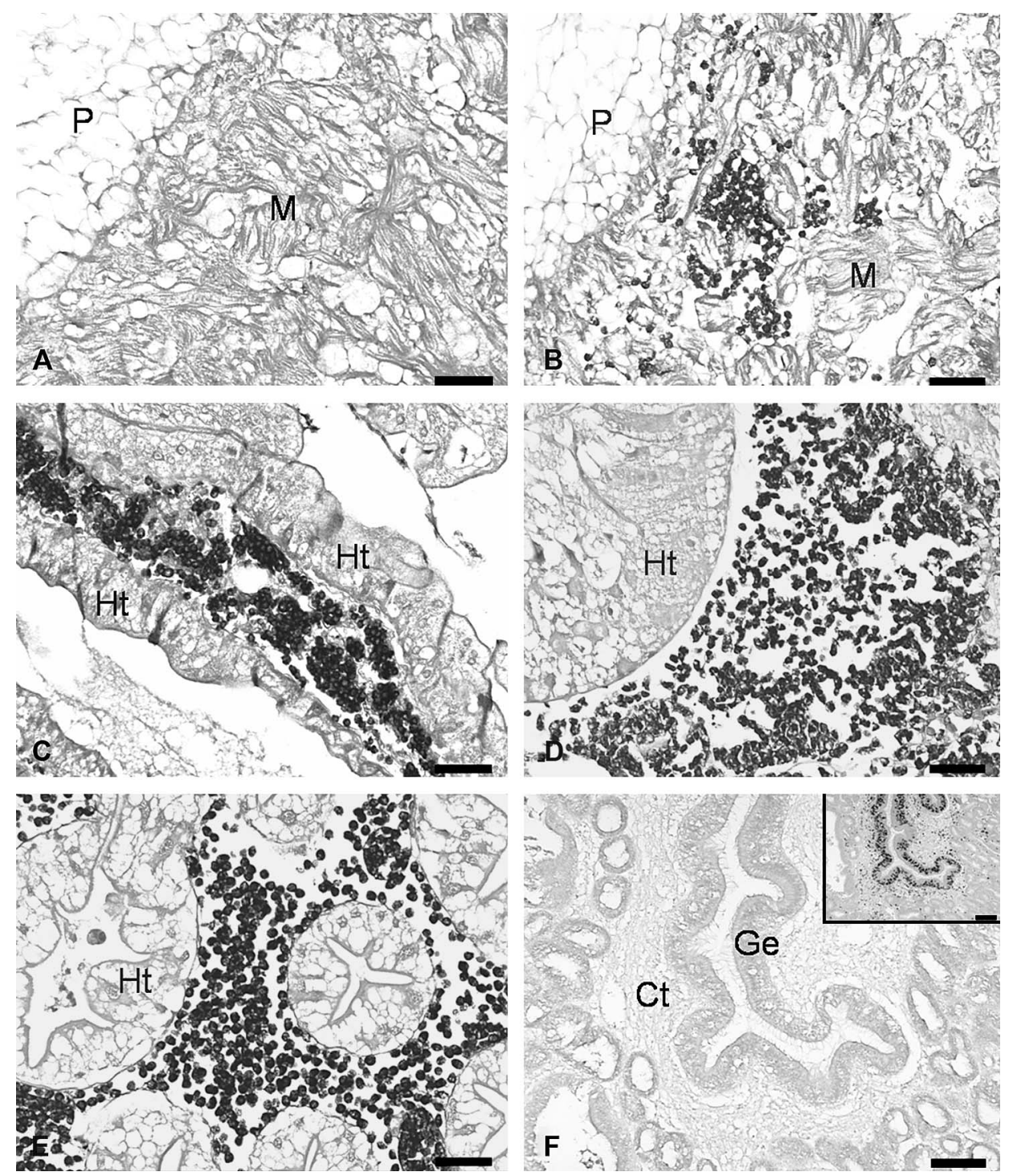

Figure 5. Host tissue sections reacted with the H-680 and H-1425 probe by ISH. Positively stained Hematodinium sp. parasites are shown by dark staining. (A) Uninfected Callinectes sapidus heart section reacted with H-1425 probe. (B) Hematodinium sp. in C. sapidus heart section reacted with H-1425 probe. (C) Hematodinium sp. in C. sapidus hepatopancreas section reacted with H-860 probe. (D) Hematodinium sp. in Chionoecetes opilio hepatopancreas section reacted with H-1425 probe. (E) Hematodinium sp. in Nephrops norvegicus hepatopancreas section reacted with H-1425 probe. (F) Perkinsus marinus in digestive gland of Crassostrea virginica reacted with $\mathrm{H}-1425$ probe (inset shows same $C$. virginica section reacted with the Perkinsus sp. genus probe Perksp700 [Elston et al. 2004]). P, pericardium; M, myocardium; Ht, hepatopancreatic tubule; Ct, connective tissue; Ge, gut epithelium. Scale bar $=\mathbf{5 0} \boldsymbol{\mu m}$.

et al. (2006), are most likely genus specific because of the conserved nature of $18 \mathrm{~S}$ gene sequences in Hematodinium spp. (Hudson \& Adlard 1996, Small et al. 2006a).

The internal transcribed spacer regions 1 and 2 (ITS1 and ITS2) that reside in-between the $18 \mathrm{~S}, 5.8 \mathrm{~S}$ and $28 \mathrm{~S}$ ribosomal RNA genes are good targets for DNA-based species identification, because these regions diverge considerably during speciation, permitting closely related species to be identified. Species-specific assays targeting the ITS regions have been applied effectively to detect many dinoflagellates and parasites (Hamaguchi et al. 1998, Dungan et al. 2002, Litaker et al. 2003, Audemard et al. 2004, Galluzzi et al. 2004, Moss et al. 2006, Small et al. 2006a). In this study, we have sequenced multiple clones from two Hematodinium samples from C. sapidus to determine whether intraspecific polymorphisms, which are common in the ITS regions from similar organisms (Litaker et al. 2003, Brown et al. 2004), would prohibit the use of this region as a target for molecular assays. We report that the ITS1 region was well conserved in the 10 clones analyzed (Fig. 2) and that no polymorphisms were detected in the regions to which the ITS1-specific primers were designed to anneal. We observed four single polymorphisms in the 10 clones analyzed, with three of these being transitions. Given the reported error rate for Platinum high fidelity Taq $\left(4.4 \times 10^{-5}\right.$ per bp $)$, it is unlikely that these nucleotide substitutions are the result of PCR-induced mutation, and are likely repeat motifs in the ITS1 region that contain random mutations. Analysis of Hematodinium infections in C. sapidus samples from Georgia by the PCR-RFLP 
assay indicated that extensive intraspecific polymorphisms were not present in either of the ITS1 primer anchor regions or the Bsg I restriction enzyme recognition site.

Significantly, the primers designed in this study also amplified the ITS1 region from Hematodinium spp. infecting $P$. trituberculatus and L. depurator (Fig. 3A). In spite of this, the Hematodinium sp. infecting $C$. sapidus could be distinguished from the others by a restriction enzyme digestion of the amplification products ( $B s g$ I), resulting in a diagnostic twoband digestion profile (Fig. 3B). Furthermore, the parasite species infecting $P$. trituberculatus and $L$. depurator could also be reliably distinguished from each other (and from the species infecting $C$. sapidus) by using the enzymes $S f c$ I and Blp I (respectively) in place of $B s g \mathrm{I}$ in the restriction enzyme digestion assay (data not shown). Given that the primers were able to bind to the ITS1 region in these Hematodinium species, and that restriction enzyme digestion of amplicons could separate these, we suggest that these may represent three similar, yet distinct species of Hematodinium. Sequencing and analysis of the ITS1 regions from these species, as well as data for other gene regions are needed to confirm this hypothesis. No amplicon was produced using template DNA from the Hematodinium spp. infecting C. opilio, $N$. norvegicus, $P$. bernhardus, or C. pagurus, indicating that these parasite species are different from the species in the portunid crabs. This hypothesis is further supported by the 18S-ITS1-based PCR assay of Small et al. (2006a), which gave an amplification product using DNA from Hematodinium infected $N$. norvegicus and $C$. pagurus, but not for that from $C$. sapidus.

Since the initial report of Hematodinium sp. infection in Callinectes sapidus from the eastern United States (Newman \& Johnson 1975), the parasite has been reported from the spider crab, Libinia emarginata, the stone crab, Menippe mercinaria, the lesser blue crab, Callinectes similis, the xanthid crab, Neopanope sayi, the portunid crab, Ovalipes ocellatus, and cancer crabs, Cancer irroratus and C. borealis (MacLean \& Ruddell 1978, Messick \& Shields 2000, Sheppard et al. 2003). These reports were based on microscopic observation of parasite stages in fixed hemolymph and tissue preparations, and in Sheppard et al. (2003) by PCR using the Hematodinium 18S-based primers of Gruebl et al. (2002). What is unknown is whether these crustaceans represent alternate hosts for the same species of parasite infecting C. sapidus, or whether they are different species of parasites. Sheppard et al. (2003) sequenced the 195-bp 18S rRNA gene fragments amplified from infected C. sapidus, M. mercinaria, and L. emarginata and concluded that these hosts are all infected with the same species. However, the 18S rRNA gene is highly conserved in similar species complexes (Skovgaard et al. 2005), and is known to be conserved in Hematodinium spp. (Hudson \& Adlard 1996). It is erroneous, therefore, to infer species identifications based solely on this region. The PCRRFLP assay designed in this study would allow for the more accurate assessment of whether the multitude of other crab hosts are infected with the same species as that found in C. sapidus. Alternatively, the ITS1-targeted PCR primers could be used to amplify and sequence almost the entire ITS1 region for analysis and comparisons among isolates.

The use of a specific diagnostic assay and DNA probes for the Hematodinium sp. infecting $C$. sapidus will improve estimates of disease prevalence, especially given the potential for occult infections (Shields \& Squyars 2000). Seasonality has emerged as a significant epidemiological feature in virtually all Hematodinium-host systems studied to date. In the coastal bays of Maryland, Virginia, and Georgia, prevalence shows regular sharp peaks in late autumn with a rapid decline in winter followed by moderate increases in spring (Messick \& Shields 2000, Sheppard et al. 2003). Epizootics can reach $100 \%$ prevalence during outbreaks (Messick 1994) with most of the diseased crabs likely dying of the infection (Messick \& Shields 2000, Shields \& Squyars 2000). Other Hematodinium infections show strong seasonality but the patterns differ (see Stentiford \& Shields 2005); yet, in all of these systems, a nadir occurs when infections are extremely low or even undetectable in host populations. These nadirs are suggestive of an external reservoir or a latency of infection, which is no doubt linked to the parasite life cycle. Frischer et al. (2006) provide evidence that for the Hematodinium sp. infecting $C$. sapidus, waterborne disease transmission is possible via infective dinospores. In this scenario, the PCRRFLP and DNA probes would be useful for identifying infected hosts and tissues, detecting life cycle stages in environmental samples, and localizing parasites in field studies and laboratory challenge experiments.

\section{ACKNOWLEDGMENTS}

The authors thank D. Taylor (Fisheries and Oceans, Canada), G. Stentiford (Centre for Environment, Fisheries \& Aquaculture Science), M. Frischer (Skidaway Institute of Oceanography), T. Meyers (Alaska Department of Fish and Game), and W. Xu (Marine Fisheries Research Institute of Zhejiang) for their help in obtaining samples of Hematodinium infected hosts. The authors also thank K. Wheeler for her able histological preparations, and $\mathrm{J}$. Moss for the image of the $C$. virginica section reacted with the Perkinsus sp. genus probe and her helpful critique of the manuscript. This is VIMS contribution No. 2803.

\section{LITERATURE CITED}

Audemard, C., K. S. Reece \& E. M. Burreson. 2004. Development of real-time PCR for the detection and quantification of the protistan parasite Perkinsus marinus. Appl. Environ. Microbiol. 70:66116618.

Bargues, M. D., A. Marcilla, J. M. Ramsey, J. P. Dujardin, C. J. Schofield \& S. Mas-Coma. 2000. Nuclear rDNA-based molecular clock of the evolution of triatominae (Hemiptera: Reduviidae), vectors of Chagas disease. Mem. Inst. Oswaldo Cruz 95:567-573.

Bower, S. M., G. R. Meyer \& J. A. Boutillier. 1993. Disease of spot prawns (Pandalus platyceros) caused by intracellular bacterium and a Hematodinium-like protozoan. J. Shellfish Res. 12:135a.
Briggs, R. P. \& M. McAliskey. 2002. The prevalence of Hematodinium in Nephrops norvegicus from the Western Irish Sea. J. Mar. Biol. Ass. U. K. 82:427-433.

Brown, G., K. L. Hudson \& K. S. Reece. 2004. Genetic variation at the ITS and ATAN loci among and within cultured isolates of Perkinsus marinus. J. Eukaryot. Microbiol. 51:312-320.

Bushek, D. \& S. K. Allen. 1996. Races of Perkinsus marinus. J. Shellfish Res. 15:103-107.

Chatton, É. \& R. Poisson. 1931. Sur l'existence, dans le sang des Crabes, de Péridinien parasites: Hematodinium perezi n. g., n. sp. (Syndinidae). C. R. Seances Soc. Biol. Paris 105:553-557. 
Cunningham, C. O. 2002. Molecular diagnosis of fish and shellfish diseases: present status and potential use in disease control. Aquaculture 206:19-55.

Dungan, C. F., R. M. Hamilton, K. L. Hudson, C. B. McCollough \& K. S. Reece. 2002. Two epizootic infectious diseases in Chesapeake Bay commercial clams Mya arenaria and Tagelus plebius. Dis. Aquat. Org. 50:67-78.

Elston, R., C. Dungan, T. Meyers \& K. S. Reece. 2004. Perkinsus sp. infection risk for Manila clams, Venerupis philippinarum (Admas and Reeve 1850) on the Pacific coast of North and Central America. J. Shellfish Res. 23:101-105.

Field, R. H. \& P. L. Appleton. 1995. A Hematodinium-like dinoflagellate infection of the Norway lobster Nephrops norvegicus: observations on pathology and progression of infection. Dis. Aquat. Org. 22:115-128

Field, R. H. \& P. L. Appleton. 1996. An indirect fluorescent antibody technique for the diagnosis of Hematodinium sp. infection of the Norway lobster, Nephrops norvegicus. Dis. Aquat. Org. 24:199204.

Field, R. H., C. J. Chapman, A. C. Taylor, D. M. Neil \& K. Vickerman. 1992. Infection of the Norway lobster Nephrops norvegicus by a Hematodinium-like species of dinoflagellate on the West Coast of Scotland. Dis. Aquat. Org. 13:1-15.

Flores, B. S., M. E. Siddall \& E. M. Burreson. 1996. Phylogeny of the Haplosporidia (Eukaryota: Alveolata) based on small subunit ribosomal RNA gene sequence. J. Parasitol. 82:616623.

Frischer, M. E., R. F. Lee, M. A. Sheppard, A. Mauer, F. Rambow, M. Neumann, J. E. Brofft, T. Wizenmann \& J. M. Danforth. 2006. Evidence for a free-living life stage of the blue crab parasitic dinoflagelate, Hematodinium sp. Harmful Algae 5:548-557.

Galluzzi, L., A. Penna, E. Bertozzini, M. Vila, E. Garces \& M. Magnani. 2004. Development of a real-time PCR assay for rapid detection and quantification of Alexandrium minutum (a dinoflagellate). Appl. Environ. Microbiol. 70:1199-1206.

Grossel, G. W., J. Handlinger, S. Battaglene \& B. L. Munday. 2005. Diagnostic polymerase chain reaction assay to detect Kudoa neurophila (Myxozoa: Multivalvulida) in a marine finfish hatchery. Dis. Aquat. Org. 64:141-149.

Gruebl, T., M. E. Frischer, M. Sheppard, M. Neumann, A. Maurer \& R. F. Lee. 2002. Development of an 18S rRNA gene-targeted PCRbased diagnostic for the blue crab parasite Hematodinium sp. Dis. Aquat. Org. 49:61-70.

Hamaguchi, M., N. Suzuki, H. Usuki \& H. Ishioka. 1998. Perkinsus protozoan infection in short-necked clam Tapes (= Ruditapes) philippinarum in Japan. Fish Pathol. 33:473-480.

Hudson, D. A. \& R. D. Adlard. 1994. PCR-techniques applied to Hematodinium spp. and Hematodinium-like dinoflagellates in decapod crustaceans. Dis. Aquat. Org. 20:203-206.

Hudson, D. A. \& R. D. Adlard. 1996. Nucleotide sequence determination of the partial SSU rDNA gene and ITS1 region of Hematodinium cf. perezi and Hematodinium-like dinoflagellates. Dis. Aquat. Org. 24:55-60.

Hudson, D. A. \& J. D. Shields. 1994. Hematodinium australis n.sp., a parasitic dinoflagellate of the sand crab Portunus pelagicus from Moreton bay, Australia. Dis. Aquat. Org. 19:109-119.

Le Roux, F., C. Audemard, A. Barnaud \& F. Berthe. 1999. DNA probes as potential tools for the detection of Marteilia refringens. Mar. Biotechnol. 1:588-597.

Litaker, R. W., M. W. Vandersea, S. R. Kibler, K. S. Reece, N. A. Stokes, K. A. Steidinger, D. F. Millie, B. J. Bendis, R. J. Pigg \& P. A. Tester. 2003. Identification of Pfiesteria piscicida (Dinophycae) and Pfiesteria-like organisms using internal transcribes spacerspecific PCR assays. J. Phycol. 39:754-761.

MacLean, S. A. \& M. C. Ruddell. 1978. Three new crustacean hosts for the parasitic dinoflagellate Hematodinium perezi (Dinoflagellata: Syndinidae). J. Parasitol. 64:158-160.
Medlin, L., H. J. Elwood, S. Stickel \& M. L. Sogin. 1988. The characterization of enzymatically amplified eukaryotic 16S-like rRNA coding regions. Gene 7:491-499.

Messick, G. A. 1994. Hematodinium perezi infections in adult and juvenile blue crabs Callinectes sapidus from coastal bays of Maryland and Virginia, USA. Dis. Aquat. Org. 19:77-82.

Messick, G. A. \& J. D. Shields. 2000. Epizootiology of the parasitic dinoflagellate Hematodinium sp. in the American blue crab Callinectes sapidus. Dis. Aquat. Org. 43:139-152.

Meyers, T. R., T. M. Koeneman, C. Botelho \& S. Short. 1987. Bitter crab disease: a fatal dinoflagellate infection and marketing problem for Alaskan Tanner crabs Chionoecetes bairdi. Dis. Aquat. Org. 3:195-216.

Moss, J. A., E. M. Burreson \& K. S. Reece. 2006. Advanced Perkinsus marinus infections in Crassostrea ariakensis maintained under laboratory conditions. J. Shellfish Res. 25:65-72.

Newman, M. W. \& C. A. Johnson. 1975. A disease of blue crabs (Callinectes sapidus) caused by a parasitic dinoflagellate, Hematodinium sp. J. Parasitol. 63:554-557.

Rublee, P. A., J. Kempton, E. Schaefer, J. M. Burkholder, H. B. Glasgow \& D. Oldach. 1999. PCR and FISH detection extends the range of Pfiesteria piscicida in estuarine waters. Va. J. Sci. 50: 325-336.

Shaw, B. L. \& H. I. Battle. 1957. The gross and microscopic anatomy of the digestive tract of the oyster, Crassostrea virginica (Gmelin). Can. J. Zool. 35:325-347.

Sheppard, M., A. Walker, M. E. Frischer \& R. F. Lee. 2003. Histopathology and prevalence of the parasitic dinoflagellate Hematodinium sp, in crabs (Callinectes sapidus, Callinectes similes, Neopanope sayi, Libinia emarginata, Menippe mercenaria) from a Georgia estuary. J. Shellfish Res. 22:873-880.

Shields, J. D. \& C. M. Squyars. 2000. Mortality and hematology of blue crabs, Callinectes sapidus, experimentally infected with the parasitic dinoflagellate Hematodinium perezi. Fish. Bull. (Wash. D. C.) 98:139-152.

Shields, J. D., C. Scanlon \& A. Volety. 2003. Aspects of the pathophysiology of blue crabs, Callinectes sapidus, infected with the parasitic dinoflagellate Hematodinium perezi. Bull. Mar. Sci. 72:519-535.

Skovgaard, A., R. Massana, V. Balague \& E. Saiz. 2005. Phylogenetic position of the copepod-infesting parasite Syndinium turbo (Dinoflagellata, Syndinea). Protist 156:413-423.

Small, H. J. 2004. Infections of the Norway lobster, Nephrops norvegicus (L.) by dinoflagellate and ciliate parasites. PhD Thesis. University of Glasgow, Scotland, UK, $216 \mathrm{pp}$.

Small, H. J., S. Wilson, D. M. Neil, P. Hagan \& G. H. Coombs. 2002. Detection of the parasitic dinoflagellate Hematodinium in the Norway Lobster (Nephrops norvegicus) by ELISA. Dis. Aquat. Org. 52:175-177.

Small, H. J., D. M. Neil, A. C. Taylor, R. J. A. Atkinson \& G. H. Coombs. 2006a. Molecular detection of Hematodinium spp. in Norway lobster Nephrops norvegicus and other crustaceans. Dis. Aquat. Org. 69:185-195.

Small, H. J., J. A. Moss, J. D. Shields \& K. S. Reece. 2006b. Identification of Hematodinium species using ITS rRNA sequence variation. 11th International Congress of Parasitology. Meeting Abstract. Glasgow, Scotland, U.K.

Stentiford, G. D. \& J. D. Shields. 2005. A review of the parasitic dinoflagellates Hematodinium species and Hematodinium-like infections in marine crustaceans. Dis. Aquat. Org. 66:47-70.

Stentiford, G. D., D. M. Neil \& G. H. Coombs. 2001. Development and application of an immunoassay diagnostic technique for studying Hematodinium infections in Nephrops norvegicus populations. Dis. Aquat. Org. 46:223-229.

Stentiford, G. D., M. Green, K. Bateman, H. J. Small, D. M. Neil \& S. W. Feist. 2002. Infection by a Hematodinium-like parasitic dinoflagellate causes Pink Crab Disease (PCD) in the edible crab Cancer pagurus. J. Invertebr. Pathol. 79:179-191. 
Stewart, J. E., J. W. Cornick, B. M. Zwicker \& B. Arie. 2004. Studies on the virulence of Aerococcus viridans (var.) homari, the causative agent of gaffkemia, a fatal disease of homarid lobsters. Dis. Aquat. Org. 60:149-155.

Tärnlund, S. 2000. A comparison of two methods for identifying and assessing the parasitic dinoflagellate Hematodinium sp. in Norway lobster (Nephrops norvegicus). M.Sc. Thesis, University of Götenborg, Sweden. 38 pp.

Taylor, D. M. \& R. A. Khan. 1995. Observations on the occurrence of Hematodinium sp. (Dinoflagellata: Syndinidae), the causative agent of bitter crab disease in Newfoundland snow crab (Chionoecetes opilio). J. Invertebr. Pathol. 65:283-288.

Wang, Q., B. L. White, R. M. Redman \& D. V. Lightner. 1999. Per os challenge of Litopenaeus vannamei postlarvae and Farfantepenaeus duorarum juveniles with six geographic isolates of white spot syndrome virus. Aquaculture 170:179-194.

Wilhelm, G. \& E. Mialhe. 1996. Dinoflagellate infection associated with the decline of Necora puber crab populations in France. Dis. Aquat. Org. 26:213-219. 